\title{
Development of resource saving and resource efficiency as the most important factor in the industrial development in the Arctic
}

\author{
Janna Mankulova ${ }^{1 *}$ and Alexander Vorotnikov $^{1,2}$ \\ 1'PORA' expert center (Arctic Development Project Office), 123056, 26/2 Zoologicheskaya str., Moscow, Russia \\ ${ }^{2}$ Candidate of Chemical Sciences, Russian Academy of National Economy and Public Administration, 119571, 82 Vernadsky Ave., \\ Moscow, Russia
}

\begin{abstract}
Research in the sphere of the Arctic industrial development often leads to the identification of clear regulatory gaps of a systemic nature. A particular example is the issue of legislative regulation of the involvement of secondary raw materials, fuel and energy resources in economic use and property turnover in the context of resource conservation and resource efficiency. In this case, secondary resources are not subject to independent regulation in general, but only as one of the elements of activities related to environmental protection. Accordingly, the conditions for the development of a system of production and consumption wastes' effective management, the creation of a recycling industry, including the reuse of such waste, have not been formed yet. The results of the analysis given in this research paper clearly indicate the lack of development of mechanisms for stimulating the use of non-target materials and substances. Industrial enterprises that use secondary resources in production do not currently receive special advantages within the framework of the implemented industrial policy. System benefits are universal and directly related to commodity production only. However, it is necessary to apply measures to encourage industrial activities to implement projects involving the reuse of secondary resources in production, including in the Russian Arctic.
\end{abstract}

\section{Introduction}

Please write your text here According to the authors, the prospects for the implementation and development of state support in the sphere of secondary resources should be analyzed in the context of general ideas about resource conservation as a process designed and implemented at the level of the national economy.

The practice of reusing the most valuable technological waste in terms of raw materials has already developed at the level of individual industry segments. There is a measurable demand for a number of useful fractions, such as scrap and ferrous /non-ferrous metals waste, high-grade waste paper, textile, polymer and wood waste, cullet, part of the mineral waste of the electric power industry, metallurgy, chemistry and construction materials industry. This kind of technological waste has been used on an industrial scale for a relatively long time as secondary resources in the ferrous and non-ferrous metallurgy, pulp, paper and textile industries, and in the production of goods made of thermoplastics. However, this practice is not expected to generate any systematic approaches. A larger volume of fractions extracted from waste is used for economic purposes on a much smaller scale, while some of them automatically fall under the legal regime of waste, which limits their permitted economic turnover either to refusal to use (burial, neutralization), or to disposal.

\section{Main part}

The issue of resource conservation is complex, it covers the areas with a high level of state influence, including technical and technological, price, credit, investment, foreign economic, and environmental spheres. In this regard, the formation and development of resource conservation is impossible without the participation of the state, state regulatory instruments, including economic incentives for targeted activities of economic entities. This problem is particularly relevant for the Arctic. Currently, the country is actively developing a new policy for the industrial development of the Russian Arctic. Recently, the President of Russia signed Decree No. 164 of 05.03.2020, which approved the "Fundamentals of state policy in the Arctic and national security until year 2035" (hereinafter — the Fundamentals) [1]. The Fundamentals set out the goals of the state policy of the Russian Federation in the Arctic. According to the authors, the important ones are:

a) improving the quality of life of the population of the Arctic zone belonging to the Russian Federation, including representatives of small-numbered peoples;

b) accelerating the economic development of the territories of the Arctic zone belonging to the Russian

* Corresponding author: vdep14@,yandex.ru 
Federation and increasing their contribution to the country's economic growth;

c) environmental protection in the Arctic, protection of native habitat and small peoples' traditional life;

Implementation of these current goals is impossible without changing the paradigm of industrial development of the Russian Arctic. Industrial development of the Arctic should be based on resource conservation and resource efficiency. According to the law draft (hereinafter - Law draft on secondary resources) prepared by the Ministry of Industry and Trade [2]:

a) resource efficiency of industry - a characteristic of industry that reflects the rational use and costeffectiveness of spending primary and secondary resources in the implementation of economic activities, expressed in terms of resource conservation and resource efficiency;

b) resource conservation in industry implementation of organizational, legal, technical, technological, economic and other measures aimed at reducing the volume of primary and secondary resources used and lost while maintaining the beneficial effect of their use, including the volume of economic benefits created;

It is assumed that the Law draft on secondary resources will contribute to the inclusion of issues of resource conservation and resource efficiency of industry in the sphere of formation and implementation of environmental industrial policy in the Russian Federation, with the allocation of two main areas:

a) modernization of industry based on the best available technologies;

b) involvement of secondary resources in economic activity, which is especially important for the Russian Arctic.

Moreover, business activity in the Arctic can now claim support from the government of the Russian Federation, which, we hope, will revive investment activity in the region and lead to an increase in industrial development of the Arctic. In particular, the Federal law draft "On support of business activities in the Russian Arctic", which has already passed the first reading in the State Duma of the Russian Federation, is aimed at this [3].

Returning to the current status of the issue, it is necessary to note the following.

Encouraging industrial entities to use material, financial and natural resources efficiently and effectively, and to ensure the improvement of resourcesaving and environmentally friendly technologies is one of the general objectives of industrial policy, as set out in Article 2 of the Federal law "On industrial policy in the Russian Federation" of 31.12.2014 No. 488-FZ.

The request to expand the grounds for providing incentives to industrial entities in the implementation of measures to achieve the target values of resource conservation and resource efficiency indicators for individual industries, along with economic grounds, is due to the content of the state's governing instructions.

In particular, according to the instructions of the President of the Russian Federation from 15.11.2017 No.
2319 in the sphere of waste management regulation, the Russian Federation government shall provide the State Duma of the Federal Assembly of the Russian Federation with a draft of a Federal law on secondary material resources regulation. When making decisions on providing them with state support, they should consider the issue of stimulating the demand for their products and determine the conceptual apparatus regarding eco-techno-parks in the sphere of waste management, as well as provide for standard requirements, ensuring the expansion of the range of production of goods made from secondary material resources.

However, the policy on resource conservation and resource efficiency is not fully formed. There are currently no economic levers for the development of relations to involve secondary production resources in turnover through positive and negative incentives for enterprises, both as a part of the institute of resource conservation and resource efficiency and as a part of the institute of best available technologies as an active mechanism for implementing state industrial policy.

Cross-sectoral measures to support the industry, administered by the Ministry of Industry and Trade, are not in any connection with the resource saving and resource efficiency, at least for the reason that these indicators and especially their target values aren't provided in the relevant normative legal acts (Decree of 03.01.2014 № 3 [4] and of 25.05.2017 № 634 [5]).

Resource conservation and resource efficiency are, for example, mentioned in the decision of the Russian Federation Government dated 03.01.2014 No. 3 (paragraph 6, subparagraph "a" point 3). They were found earlier, for example, in the decision of the Russian Federation Government № 1312 dated 30.12.2013 and valid until 01.01.2020 (subparagraph "e" paragraph 3). The terminology of the relevant resolutions of the Russian Federation Government is about "improving energy efficiency and resource conservation" as one of a number of general goals in the context of identifying certain activities of subjects in the sphere of industry within the supported priority area of civil industry. At the same time, these areas are in any case presupposed in the State program "Development of industry and increase of its competitiveness", approved by Russian Federation Government decree of 15.04.2014 No. 328. In other words, the goal of "improving energy efficiency and resource conservation" is essentially nominal.

It should be noted that in accordance with paragraph 2 of the Order of technological areas determination under the relevant state program of the Russian Federation "Development of industry and increasing its competitiveness", the priority areas of civil industry, approved by Russian Minpromtorg Order of 21.09.2017 No. 3249 , the priority is given to technology areas, the implementation of which improves energy efficiency and resource conservation. However, the listed criteria for selecting technological areas for support purposes under the Russian Federation Government Decree dated 16.12.2019 No. 1649 don't include "energy efficiency and resource conservation". 
This explains the systematic lack of mentioning this institute further - neither in the form of submitting proposals for the formation of technological areas list in order to conduct a competition for grants for research and development work nor as part of the tender documentation for competitive selection for the right to receive subsidies from the Federal budget given to Russian organizations to partially compensate the costs of conducting research and development work in priority areas of the civil industry as part of complex investment projects implemented by such organizations.

Under these circumstances, we come to the irrefutable conclusion that in the current system of industry supporting measures, the activities of subjects in the sphere of industry to improve resource conservation and resource efficiency are not allocated (they do not have their own indicators) and, accordingly, are not evaluated.

Analyzing the fundamental possibility of obtaining state support in the implementation of activities on improving resource conservation and resource efficiency, we shall note that individual manufacturing enterprises that produce finished goods using secondary resources being the main goal of their economic activity (under Section $\mathrm{C}$ of All-Russian classifier of economic activity types 2), under certain conditions, can apply for it on a general basis. We repeat that such grounds are not in any way connected with the achievement of specific values of resource saving and resource efficiency indicators. The resolutions of the Russian Federation Government in force in this section are intended only to increase the volume of industrial production, which is why certain legal relations in the sphere of resource conservation and resource efficiency do not find their place in the general system of support measures.

In the general mainstream, there are other identified support measures are across the entire list of national projects [6].

Developing the topic of resource conservation and resource efficiency support, it is impossible to ignore the institute of the best available technologies. The connection between them is not direct, but obvious [7].

The institute of the best available technologies, which was originally enshrined in environmental legislation, has recently received the prospect of positive legal regulation within the framework of industrial policy.

In his Decree No. 204 of 07.05.2018, which defines the national goals and strategic development objectives of the Russian Federation for the period up to year 2024, the President of the Russian Federation identified the use of an environmental management system based on the use of the best available technologies as a task that needs to be addressed in the sphere of ecology.

In order to implement the decree of the President of the Russian Federation, the national project "Ecology" was developed (the passport was approved by the Presidium of the Presidential Council for strategic development and national projects (Protocol No. 16 of 24.12.2018)), which includes the Federal project "Introduction of the best available technologies". Only one special event is identified as part of the project activities. This is the resolution of the Russian Federation Government No. 541 "On approval of the Rules for granting subsidies from the Federal budget to Russian organizations to reimburse the costs of paying coupon income on bonds issued as part of investment projects to introduce the best available technologies" dated 30.04.2019. Despite this, according to the Minister of Industry, D. Manturov, modern industrial policy "assumes simultaneous and coordinated solution of both the tasks of accelerating economic growth and technological renewal, as well as the tasks of increasing resource and energy efficiency and reducing the negative impact of production on the environment and public health. Best available technologies (BAT) are a new tool for Russia's environmental industrial policy. BAT should be considered simultaneously from the perspective of both environmental and economic regulation. The task of coordinating industrial and environmental policy measures is determined by the fact that in conditions when production needs intensive technological renewal, greening of industry can and should become a driver and an integral element of its development" [8].

As can be seen from the title of the document, it addresses category I objects and subjects related to the areas of the best available technologies application. In other words, they are talking about the potential partial financing of the costs of some of the three hundred dangerous pollutants when they make and implement a decision to raise funds by issuing bonds.

Investment costs are the purchase of equipment and technical devices that reduce negative impacts on the environment, as well as design and survey, construction, installation and commissioning works for the gradual achievement of technological standards, and (or) standards for allowable emissions and (or) the permissible concentrations of toxic substances, substances with carcinogenic, mutagenic properties, established in accordance with the legislation in the sphere of environmental protection. For the first time the government of the Russian Federation, providing for the grant, administrated by Ministry of Industry and Trade, operates with the concept of eco-efficiency. Yet this document is a not related to resource conservation and resource efficiency either.

With regard to the application of financial support from the Industrial Development Fund under current conditions as a measure to stimulate activities to improve resource conservation and resource efficiency, using the example of re-involving secondary resources in economic turnover, it should also be concluded that there are no special grounds, including advantages, for the relevant industrial entities and their investment projects.

Industrial enterprises engaged in the re-involvement of secondary resources in production can be potential recipients of a loan from the Industrial Development Fund on an equal basis with organizations that use natural resources in production, only if they meet the program requirements, similar for everybody.

For example, an enterprise has the right to apply for project financing from borrowed funds of the Industrial Development Fund under the "Development Projects" program for measures to develop a new technology used 
when secondary resources are included in the production of finished goods, on the following basic conditions:

a) manufactured products have competitive advantages over Russian or foreign analogues on the market, or their technical and economic parameters correspond to the world level or exceed it;

b) sales of manufactured products are aimed at replacing imports on the domestic market, including assigning the product to the category of importsubstituting products in accordance with industry plans approved by the Federal Executive body authorized by the Russian Federation Government;

c) sales of manufactured products are exportoriented;

d) the new technologies being introduced are among the priority areas of science, technology and technique development in the Russian Federation, in particular, they correspond to the list of critical technologies approved by decree of the President of the Russian Federation No. 899 of 07.07.2011;

e) the novelty of technical solutions related to the Russian technical level is confirmed;

f) the products obtained during the project implementation are industrial products that have no analogues produced in the Russian Federation.

Summarizing the existing support measures, we should conclude that in all cases, resource conservation and resource efficiency do not have their own indicators, and in some cases, they are not mentioned at all. This project supports the creation of industrial infrastructure, research and development activities, and the introduction of products into commercial operation. At the same time, manufacturing enterprises that use secondary resources in the production of finished goods under section $\mathrm{C}$ of All-Russian classifier of economic activity types 2 can potentially apply for support under all the previously listed support measures only if they are assigned to priority sectors of civil industry under the State program "Development of industry and increasing its competitiveness" (industry subprograms 1-4), and without receiving advantages over other applicants.

It should be recognized that recently the expert community has been actively developing an approach according to which the issues of resource conservation and resource efficiency are included in the sphere of industrial policy of the Russian Federation.

The Ministry of Industry and Trade submitted a Federal law draft (the law draft on secondary resources) to the Russian Federation Government: "On amendments to certain legislative acts of the Russian Federation (in the part of legal regulation of relations in secondary resources management and the expertise of poor-quality and dangerous food products, materials and goods withdrawn from circulation)", developed for the purpose of implementation of subparagraph "g" point 1 of the list of orders by the Russian Federation President of 15 November 2017 \# Pr-2319, as well as a part of the execution of instructions of the Deputy Prime Minister of the Russian Federation A. G. Khloponin dated November 22, \# AKh-P9-7749 and Deputy Prime Minister of the Russian Federation A. V. Gordeev dated June 29, 2018 \# AG-P9-3799. According to the authors, the adoption of the law draft and its implementation are very relevant for the Russian Federation. Linking resource conservation and resource efficiency with industrial policies and industrial development strategies (industry, regional, and corporate) makes it possible to effectively transit to a low - carbon economy, and in the future, to the most desirable phenomenon - cyclical economy [9]. This industrial policy is being actively developed by the European Union [10], [11], Great Britain [12], [13], Denmark [14] and other countries.

According to the authors, the most important role in the development of resource conservation and resource efficiency of industrial policy in the Russian Arctic will be played by the creation of a waste processing industry. Waste recycling and reuse is one of the important elements of the circular economy while the transition to it has three undeniable advantages. The first is to reduce the negative environmental impact by reducing the use of resources in production. The second is to reduce production costs due to a decrease in primary resources used. The third is the emergence of new markets, which means the creation of new jobs and an increase in the overall level of well-being. However, at present, according to many authors, waste processing in Russia is in its infancy [15], [16].

\section{Conclusion}

The future legal fate of the issue of expanding the grounds for applying industrial incentives to projects involving the reuse of secondary resources in production, including in the Russian Arctic, will be determined by taking into account the political will and its content.

\section{References}

1. Decree of the Russian Federation President of March 5, 2020 \# 164 "On the Basics of state policy of the Russian Federation in the Arctic for the period up to year 2035». Available online: https:/www.garant.ru/products/ipo/prime/doc/73606 526/ (2020)

2. Federal law draft "On amendments to certain legislative acts of the Russian Federation (in terms of regulation of relations on secondary resources management and the examination of low-quality and dangerous food products, materials and goods withdrawn from circulation)". Available online: http://www.consultant.ru/cons/cgi/online.cgi?req=do c\&base $=$ PRJ\&n=183580\#09213610990039137 (2020)

3. Federal law draft "On state support for entrepreneurship in the Arctic zone of the Russian Federation". Available online: http://www.consultant.ru/cons/cgi/online.cgi?req=do c\&base $=$ PRJ\&n=183845\#07670130723349657 (2020)

4. Resolution of the Russian Federation Government of 03.01.2014 No. 3 "On approval of the Rules for granting subsidies from the Federal budget to 
Russian organizations for partial reimbursement of the cost of paying interest on loans received in 2014 - 2019 in Russian credit organizations and the state corporation "Bank for development and foreign economic affairs (Vnesheconombank)", as well as in international financial organizations established in accordance with international agreements in which the Russian Federation participates, for the implementation of complex investment projects in priority areas of civil industry and (or) the payment of coupon income on bonds issued in 2014-2019 as part of the implementation of complex investment projects in priority areas of civil industry". Available online: https://base.garant.ru/70558574/ (2020)

5. The Russian Federation Government Decree No. 634 of 25.05.2017 "On granting subsidies from the Federal budget to Russian organizations to compensate for part of the costs of pilot production means batches' production and sale to consumers". Available online: https://www.garant.ru/products/ipo/prime/doc/71586 206/ (2020)

6. The Russian Federation President Decree "On national goals and strategic objectives of Russian Federation development for the period up to 2024" dated 07.05.2018 № 204. Available online: http://publication.pravo.gov.ru/Document/View/000 1201805070038 (2020)

7. State Standard 33570-2015. Interstate standard. Resource saving. Waste treatment. Identification methodology. Foreign experience. Available online: http://docs.cntd.ru/document/1200127289 (2020)

8. D. V. Manturov, Sustainable economic growth: aspects of harmonization of industrial and environmental policy in Russia, Scientific and technical bulletin of SPbSPU. Economics 11(4), 132-140 (2018). Available online: https://economy.spbstu.ru/article/2018.72.10/ (2020)

9. What resource efficiency can do for the industrial strategy. Available online: https:/greenallianceblog.org.uk/2017/03/10/whatresource-efficiency-can-do-for-the-industrialstrategy/ (2020)

10. Guide to resource efficiency in manufacturing. Available online: https://www.greenovateeurope.eu/sites/default/files/publications/REMake Greenovate!Europe\%20$\% 20$ Guide $\% 20$ to $\% 20$ resource $\% 20$ efficient $\% 20$ man ufacturing\%20(2012).pdf (2020)

11. Sustainable Industry: Going for Growth \& Resource Efficiency. Available online: https://chemicalleasing.org/sites/default/files/17_6_ Brochure-Sustainable_industry-GrowthResource_efficiency-15072011.pdf (2020)

12. Industrial Strategy: First Review. Available online: https://publications.parliament.uk/pa/cm201617/cms elect/cmbeis/616/616.pdf (2020)
13. Henningsson et al., The value of resource efficiency in the food industry: a waste minimization project in East Anglia, UK, Journal of Cleaner Production 12, (2004) 505-512. Available online: http://analyseplatformen.dk/Data/madspildsmonitor/ HTML_madspildsplatform/assets/henningsson-etal_2004_the-value-of-resource-efficiency-in-thefood-industry.pdf (2020)

14. Resource efficiency in industriesVia conclusions on Best Available Techniques (BAT) under Industrial Emissions Directive. Available online: https://www2.mst.dk/Udgiv/publications/2016/07/97 8-87-93435-95-7.pdf (2020)

15. L. A. Plotnikova, Recycling in Saint Petersburg, Synergy of Sciences 22, 798-803 (2018). Available online: http://synergy-journal.ru/archive/article2147 (2020)

16. A. A. Kirilkina, S. Yu. Tarabukina, Analysis of the solid municipal waste management market, StudArctic forum 2(6), (2017). Available online: http://saf.petrsu.ru/journal/article.php?id=1301 (2020) 